\title{
Hydrocarbon Microseepage Potential Area Exploration Using Sentinel 2 Imagery
}

\author{
Muhamad Iqbal Januadi Putra ${ }^{1, *}$, Supriatna $^{1}$, and Wikanti Asriningum ${ }^{12}$ \\ ${ }^{1}$ Department of Geography, Universitas Indonesia, Depok - Indonesia \\ ${ }^{2}$ Remote Sensing Utilization Center, National Institute of Aeronautics and Space (LAPAN), Kalisari Pasar Rebo, Jakarta - \\ Indonesia
}

\begin{abstract}
Hydrocarbon microseepage is a common phenomenon occurring in areas with the presence of onshore oil and gas reservoirs, characterized by the abnormal natural surface spectral landscape characteristics of mineral alteration features and geobotanic anomalies that can be detected by satellite imagery. Therefore, this study aims to find spatial models of oil and gas reservoirs through detection approaches of hydrocarbon microseepage and its relation with the physical condition of study area by utilized the satellite imagery. The parameters used in are alteration symptoms of clay-carbonate, ferric iron, and ferrous iron minerals, geobotanic anomaly symptoms, geology characteristic, and geomorphology characteristic. A multispectral satellite imagery of Sentinel 2 was used as an input for the directed principal component analysis (DPCA) method and vegetation index, to detect mineral alteration phenomenon and geobotanic anomaly, respectively. Then each parameter was integrated using fuzzy logic method giving a result of the distribution of hydrocarbon microseepage area. As a results, this study indicates the presence of hydrocarbon microseepage phenomenon in the research area with the extent of 488,3 Ha or 1,46\% of the total of research area. The distribution of hydrocarbon microseepage is distributed in area around oil and gas field, and also linear distributed around Merang River. The distribution of hydrocarbon microseepage in study area also agglomerated in Kasai Formation, area near fault, and the area with lacustrine landform characteristics.
\end{abstract}

Keywords : Hydrocarbon Microseepage; Remote Sensing; Sentinel 2.

\section{Introduction}

The phenomenon of hydrocarbon (HC) microseepage is a common phenomenon occurring in areas with the presence of onshore oil and gas reservoirs. The phenomenon of micro hydrocarbon seepage as a phenomenon of hydrocarbon mass movement from its original place (reservoir) to the surface of the earth [1]. The presence of the hydrocarbon micro permeability phenomenon is an important proof for the identification of onshore oil and gas reservoirs on the underlying layers that form the basis for oil and gas exploration activities [2]. According to prior research, 85\% of the world's onshore oil and gas resources are experiencing and show the existence of micro leakage and seepage that causes hydrocarbon components and content to move over oil and gas sources [3]. Meanwhile, Clarke and Cleverly [4] mentioned as much as $75 \%$ of the world's oil and gas basins show the existence of micro seepage phenomenon. The existence of hydrocarbon seepage phenomenon has an important value in oil and gas exploration activities. This makes the presence of micro hydrocarbon seepage can serve as a foundation for experts to conduct further exploration activities in the region [5].

Over the years, remote sensing techniques with satellite imagery have been used to detect any indication of such seepage systems [3] [6] [7]. Detection by satellite imagery is carried out through the process of recording the reflectance characteristics generated by HC microseepage symptom [5]. The use of remote sensing in detecting hydrocarbon seepage phenomena as an estimate of the existence of oil and gas reserves can promise big profits because the process takes place quickly and effectively, and can be done at various scales [8].

Based on the exposure, oil and gas exploration activities can actually be done through detection of $\mathrm{HC}$ microseepage detected by satellite imagery [7]. Through this approach, the presence of oil and gas reserves onshore as a source of oil and gas can be known accurately and precisely so as to increase the profitability of oil and gas production [8]. Therefore, this research was conducted with the aim to analyze the distribution of micro hydrocarbon seepage anomaly area and its relation with the physical condition of Jambi Merang area. Sentinel 2 satellite imagery in this research is used to detect the hydrocarbon microseepage as an estimation of oil and gas reservoir in onshore area because its strength in spatial resolution $(10 \mathrm{~m}, 20 \mathrm{~m}, 60 \mathrm{~m})$, temporal resolution, and the number of bandwidths than other multispectral imagery such as Landsat or ASTER. Moreover, the used of Sentinel 2 imagery also has been never conducted by other researcher in same topic.

* Corresponding author: muhamad.iqbal41@ @sci.ui.ac.id 


\section{Method}

\subsection{The Study Area}

Jambi Merang area was chosen as study area in this research since this area is one of actively exploitation onshore in Indonesia. There are three oil and gas field operations within this area. Selection of research area is done by empirical approach that active area of oil and gas exploitation will show phenomenon of hydrocarbon microseepage so that it can facilitate activity of research validation. Therefore, the Jambi Merang area which is one of the most productive onshore oil and gas blocks in Indonesia is selected as the research area. The study area can be seen in Figure 1.

Regional geology of Jambi Merang area is a tectonic back-ground line (back arc basin) that located on the South Sumatera Basin in the northern part of Palembang. The folds in this region occur in the form of Keluang Anticlin in the south, Tamiang Anticlin in the north, and Dawas Sinclin in the middle region with the main direction northwest-southeast. This folding causes the formation of oil and gas reserves in the South Sumatra Basin which is characterized by the presence of hydrocarbon seepage.

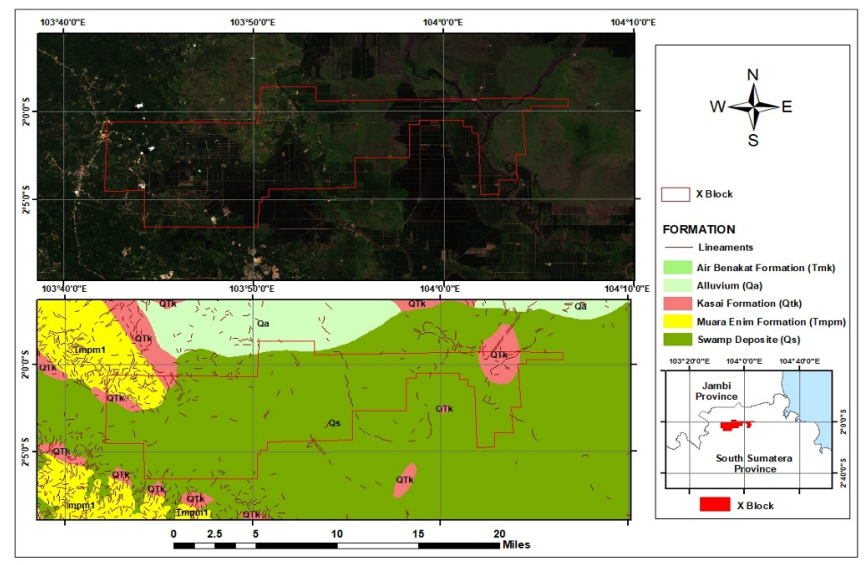

Figure 1. Jambi Merang area that located in South Sumatera Province.

\subsection{Data Acquistion \& Processing}

This study uses four data variables to detect hydrocarbon (HC) microseepage phenomena as well as the relationship of regional characteristics with the appearance of hydrocarbon microseepage phenomenon. Variables used to detect the phenomena of hydrocarbon microseepage include alteration data of indicating mineral minerals and geobotanic anomalous data obtained from Sentinel 2 imagery processing which recorded on February $15^{\text {th }}$ 2015. Mineralogical alteration data were obtained from Sentinel 2 image processing by directed principal component analysis (DPCA) method. Geobotanic anomaly data obtained from transformation of vegetation index (VI) on Sentinel 2 image bands. Meanwhile, the variables used to know the relationship between hydrocarbon (HC) microseepage phenomenon with region characteristic were conducted from geomorphology data and geological data of region that obtained by digitized from existing map.

Data processing in this research is performed through three stages, namely pre-processing of Sentinel 2 imagery, processing of seepage anomaly symptoms of hydrocarbons microseepage, and processing of physical data of region. Sentinel 2 image data processing is performed by ATCOR (Atmosphere Correction) method to get the calibration of image value that can be used for further data processing. Meanwhile, the processing of hydrocarbon (HC) microseepage anomaly is done by DPCA method and VI. DPCA method performed on mineral alteration data obtained from the processing of band ratio. Both processing anomalies are performed processing algorithm which can be seen in Table 1 .

Processed results with algorithmic function in Table 1 are further processed by fuzzy logic method. Determination of minerals alteration anomaly value is done with special equation [9] to know mineral anomaly threshold value. The equations used are:

$$
A i=\bar{X}_{ \pm \sigma}
$$

where, $\mathrm{Ai}=$ anomaly threshold value of mineral $\mathrm{i}$, $\bar{X}=$ the mean threshold value of mineral $i$, $\sigma=$ deviaton standard threshold of mineral i.

Tabel 1. Formula of data processing

\begin{tabular}{|c|c|c|}
\hline No & Anomalies & Algorithm \\
\hline 1 & Ferric Iron & SWIR 2/SWIR 1 \\
\hline 2 & Ferrous Iron & SWIR 1/Vegetation Red Edge \\
\hline 3 & Clay Carbonate & SWIR 1/SWIR 2 \\
\hline 4 & $\begin{array}{l}\text { NDVI (Normalized } \\
\text { Different Vegetation } \\
\text { Index) }\end{array}$ & $\frac{N I R-R a d}{N I R+R e d}$ \\
\hline 5 & $\begin{array}{c}\text { GNDVI (Green } \\
\text { Normalized } \\
\text { Different Vegetation } \\
\text { Index) } \\
\end{array}$ & $\frac{\text { NIR-Green }}{\text { NIR }+ \text { Green }}$ \\
\hline 6 & $\begin{array}{l}\text { SAVI (Soil Adjusted } \\
\text { Vegetation Index) }\end{array}$ & $\frac{N I R-\operatorname{Red}}{N I R+R e d+0.5}(1+0.5)$ \\
\hline 7 & $\begin{array}{c}\text { ARVI2 (Adjusted } \\
\text { Resistant Vegetation } \\
\text { Index 2) } \\
\end{array}$ & $\left(\frac{N I R-\operatorname{Red}}{N I R+\operatorname{Red}} x 1,17\right)-0,1 \varepsilon$ \\
\hline 8 & $\begin{array}{l}\text { Chlorophyll Index } \\
\text { Green }\end{array}$ & $\frac{N R R}{\text { Green }}-1$ \\
\hline 9 & $\begin{array}{l}\text { NDSI (Normalized } \\
\text { Different Senescence } \\
\text { Index) }\end{array}$ & $\frac{S W I R-\operatorname{Red}}{S W I R+\operatorname{Red}}$ \\
\hline
\end{tabular}

The analysis of the relationship between the phenomenon of hydrocarbon microseepage anomaly with the physical characteristics of the region is done by Weighted of Evidence (WoFE) method. The WoFE method is a linear logarithmic model of the Bayesian probability model used in estimating the relative importance of any evidence / phenomenon by statistical approach [10]. This method can measure the relationship and association between one phenomenon with other 
phenomena. The degree of relationship or association between phenomena is represented by the value of $w^{+}$or $w^{-}$, where the value of $w^{+}$indicates the magnitude of the positive relationship of one phenomenon with other phenomena. Meanwhile, the value of $w^{-}$denotes a negative relationship between one phenomenon with the other phenomena being tested. The $\mathrm{C}$ contrast states a magnitude of spatial correlation between biner map of phenomena and the known evidence. The formula to calculate $\mathrm{C}, w^{+}$, and $w^{-}$written as follows.

$$
\begin{aligned}
& w^{+}=\log _{e} \frac{P(X \mid D)}{P(X \mid \bar{D})} \\
& w^{-}=\log _{\theta} \frac{P(\bar{X} \mid D)}{P(\bar{X} \mid \bar{D})} \\
& C=w^{+}+w^{-}
\end{aligned}
$$

\section{Result and Dicsusiion}

\subsection{HC Microseepage Anomaly Symptoms}

Hydrocarbon (HC) microseepage symptoms can be characterized by the appearance of mineral alteration anomaly symptoms and geobotanic anomaly symptoms. Symptoms of mineral alteration anomalies are preferred from DPCA method preparations. The principle of image selection within DPCA processed products is having an eigenvector value that has a contract greater or less than the value of vegetation eigenvector (NDVI). Table 2 shows the result of DPCA processing for gaining mineral alteration information.

Table 2. The result of DPCA in Sentinel 2

\begin{tabular}{|c|r|r|r|r|}
\hline \multirow{2}{*}{ DPCA } & \multicolumn{4}{|c|}{ Eigenvector } \\
\cline { 2 - 5 } & NDVI & $\begin{array}{c}\text { Clay } \\
\text { Carbonate }\end{array}$ & $\begin{array}{c}\text { Ferric } \\
\text { Iron }\end{array}$ & $\begin{array}{c}\text { Ferrous } \\
\text { iron }\end{array}$ \\
\hline DPCA1 & 0,2804 & 0,9516 & 0,0817 & 0,0950 \\
\hline DPCA2 & 0,2472 & 0,0467 & $-0,3378$ & $-0,9069$ \\
\hline DPCA3 & 0,8470 & $-0,292$ & 0,4407 & 0,0516 \\
\hline DPCA4 & 0,377 & $-0,0809$ & $-0,8275$ & 0,4071 \\
\hline
\end{tabular}

The processing of clay carbonate, ferric iron, and ferrous iron mineral alteration anomalies were done by calculating the threshold of each band using Equation 1. The calculation results for the threshold value of the mineral anomaly alteration of each mineral on Sentinel 2 image can be seen in Table 3. In the table we can see the maximum/minimum limit value to measure the threshold of mineral alteration anomalies for processing with Sentinel image 2. This value will be the basis for the fuzzy logic (fuzzy small and fuzzy large) process which will result in the distribution of mineral alteration anomaly values.

Table 3. The threshold value of mineral alteration anomaly

\begin{tabular}{|c|c|c|c|}
\hline Alteration & Mean & SD & $\begin{array}{c}\text { Threshold } \\
\text { Value }\end{array}$ \\
\hline $\begin{array}{c}\text { Clay } \\
\text { carbonate }\end{array}$ & 64,65 & 53,9 & 118,55 \\
\hline Ferric iron & 67,45 & 57,45 & $0-10$ \\
\hline Ferrous iron & 164,58 & 70,98 & $0-93,6$ \\
\hline
\end{tabular}

Meanwhile, the pattern of geobotanic anomaly distribution was obtained from the processing of vegetation indexes of NDVI, GNDVI, SAVI, ARVI2, Chlorophyll Index Green, and NDSI. The observed vegetation conditions through the normalization of the NDVI index had a range of -0.99 to 0.93 . The GNDVI index mapped the vegetation conditions in the study area in the range of -0.99 to 0.93 ; SAVI indices in the range of -2.98 to 2.80; lastly, the ARVI2 index mapped the vegetation conditions from the range of values from 0.99 to 0.93 . Meanwhile, the chlorophyll condition of the plants obtained from Chlorophyll Index Green processing shows the range values of -1 to 22.26 and senescene phenomena are identified in the range of values -1 to 0.6 . Geobotanic anomalies symptoms are indicated by the low greenness vegetation value, low vegetation dense, low chlorophyll pigment [2] [6] [11] [12], and high of senescence phenomenon [13].

\subsection{Hydrocarbon Microseepage Potential Area}

The distribution of hydrocarbon microseepage areas is resulted from fuzzy logic processed and mainly agglomerated in the northeastern region of the southern Jambi Merang area with a linear seep morphology form of the Merang River. This region is characterized by a large threshold value of fuzzy compared to the surrounding areas $(>0.66)$. The area that has high potential of hydrocarbon microseepage is $488.3 \mathrm{Ha}$. Although agglomerated and concentrated in the northeastern region close to the Merang River, several high potential points of hydrocarbon microseepage are also present in the oil and gas field area. Areas with medium potential occurrence of micro hydrocarbon seepage are characterized by a fuzzy value of 0.33-0.66 and detected has extent area of 30,411.2 Ha. Meanwhile, areas with low potency of hydrocarbon microseepage have a fuzzy value of $0-0.33$. This area almost covers the entire research area and is spread mainly in the central and northern parts of the southern Jambi Merang area. The area for the low potential occurrence of micro hydrocarbon seepage is 2,454.5 Ha. Figure 3 shows the visualization of HC microseepage potential area in Jambi Merang area.

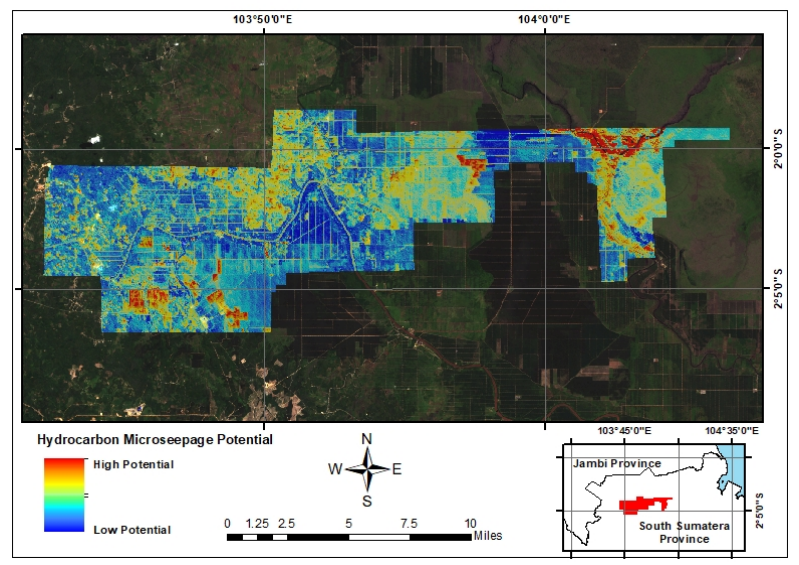

Figure 3. HC microseepage potential area. 


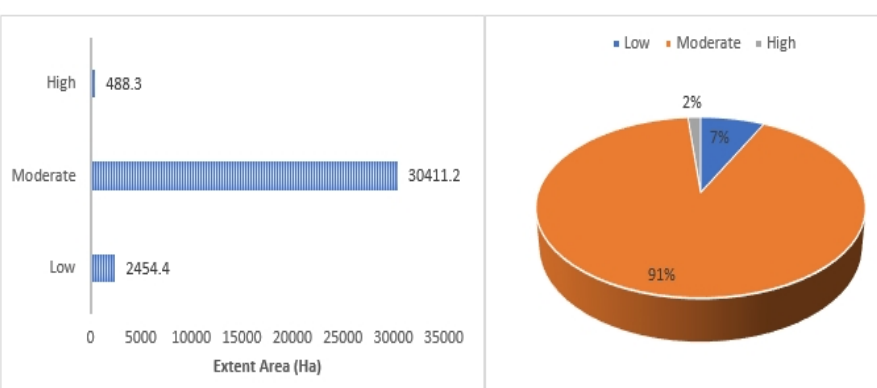

Figure 4. The extent area of HC microseepage potency (Ha).

\subsection{Relationship of Regional Characteristics with Hydrocarbon Microseepage}

The relationship between the existence of $\mathrm{HC}$ microseepage phenomenon with the condition of lithology (rock) with WoFE method can be seen in Table 4. Based on the table it can be seen that Kasai Formation is the formation that most supports the probability of $\mathrm{HC}$ microseepage phenomenon. This can be seen from the value of $w^{+}$of $2.097, w^{-}$by 0 , and a positive $\mathrm{C}$ value of 2.097. Thus, Kasai Formation has a positive relationship of 2.097 with the appearance of $\mathrm{HC}$ microseepage. The magnitude of the $\mathrm{C}$ in Kasai Formation occurs because this formation is composed by a tuffan rock type that has a good porosity in passing hydrocarbons. The hydrocarbon source itself can be derived from the improper Muara Enim Formation under Kasai Formation [14]. Meanwhile, other types of lithology, alluvium, lacustrine sediment, and Muara Enim Formation have $w^{+}$and negative $\mathrm{C}$ values which indicate a negative / reverse relationship or probability value between the phenomenon of $\mathrm{HC}$ microseepage with very low types of lithology.

Nevertheless, partially, the lithologic area of the swamp / lacustrine sediment is a lithology that has a high probability of occurrence of micro hydrocarbon seepage. Swamp sediments have a point of seepage appearance of 125 points, while Kasai Formation only raises the point of incidence of 54, alluvium by 1 point, and Muara Enim Formation by 1 point. This may be due to the bias of the WoFE method in measuring the probability of an event based on the size of the area being measured.

Table 4. Association between lithology and HC microseepage

\begin{tabular}{|c|c|c|c|c|c|}
\multicolumn{7}{c|}{ potency } \\
\hline $\begin{array}{c}\text { Lithology/ } \\
\text { Formation }\end{array}$ & $\begin{array}{c}\text { Extent } \\
\text { Area } \\
\left(\mathbf{k m}^{2}\right)\end{array}$ & $\begin{array}{c}\text { Evident } \\
\text { Points }\end{array}$ & $\mathbf{w}^{+}$ & $\mathbf{w}^{-}$ & $\mathbf{C}$ \\
\hline Kasai & 16,7 & 54 & 2,097 & 0 & 2,097 \\
\hline Aluvium & 6,12 & 1 & $-1,20$ & $\begin{array}{c}0,00 \\
3\end{array}$ & $-1,203$ \\
\hline $\begin{array}{c}\text { Lacustrine } \\
\text { (Swamp) }\end{array}$ & 296,03 & 125 & $-1,228$ & 0,01 & $-1,238$ \\
\hline $\begin{array}{c}\text { Muara } \\
\text { Enim }\end{array}$ & 15,3 & 1 & $-2,15$ & $\begin{array}{c}0,00 \\
4\end{array}$ & $-2,154$ \\
\hline
\end{tabular}

Based on geological structure characteristics, the distribution of HC microseepage in Jambi Merang area is generally relatively agglomerated in areas close to the presence of fault structures. This condition is in accordance with the explanations of Hong [6], Avcioglu [9], and Asadzadeh \& Carlos [7] explaining the role of geological structures in the phenomenon of micro hydrocarbon seepage. The presence of these faults can pave the way for the process of hydrocarbon migration from the cargo to the surface.

The farther away from the fault region, the probability of occurrence of $\mathrm{HC}$ microseepage is also smaller. The data in Table 5 shows that the values of $w^{+}$ and $\mathrm{C}$ will be lower and negative in the farther buffer region. The farthest region buffer $(>500 \mathrm{~m})$ shows the lowest $w^{+}$and $\mathrm{C}$ values from all categories of buffer regions. This suggests that the probability of occurrence of a $\mathrm{HC}$ microseepage in areas far from the fault is low. The absence of fault causes the difficulty of migrating hydrocarbons due to the absence of road space or motion.

Table 5. Association between distance from fault and $\mathrm{HC}$ microseepage potency

\begin{tabular}{|c|c|c|c|c|c|}
\hline $\begin{array}{c}\text { Distance } \\
\text { from } \\
\text { Geological } \\
\text { Structure } \\
(\mathbf{m})\end{array}$ & $\begin{array}{c}\text { Extent } \\
\text { Area } \\
\left(\mathbf{k m}^{2}\right)\end{array}$ & $\begin{array}{c}\text { Evident } \\
\text { Points }\end{array}$ & $\boldsymbol{w}^{+}$ & $\boldsymbol{w}^{-}$ & $\mathbf{C}$ \\
\hline$<100$ & 21,26 & 20 & 0,61 & - & 0,614 \\
\hline $100-200$ & 22,71 & 23 & 0,698 & 0,000 & 0,698 \\
\hline $200-300$ & 21,79 & 15 & 0,221 & - & 0,222 \\
\hline $300-400$ & 20,37 & 15 & 0,337 & - & 0,339 \\
\hline $400-500$ & 19,1 & 10 & $-0,028$ & 0,002 & - \\
\hline$>500$ & 229,3 & 97 & $-0,623$ & 0,003 & - \\
\hline
\end{tabular}

Meanwhile, based on its geomorphologic characteristics, the probability of occurrence of $\mathrm{HC}$ microseepage will generally occur in areas with a swamp landform. The result of WoFE processing shows the high probability of occurrence of $\mathrm{HC}$ microseepage in region with geomorphology characteristic of swamp land. The magnitude of the potential point of occurrence of $\mathrm{HC}$ microseepage in this region is closely related to the lacustrine lithology conditions that became the hydrocarbon resource [15]. Complete information of WoFE analysis results on geomorphological characteristics can be seen in Table 6.

Table 6. Association between geomorphologyt and HC microseepage potency

\begin{tabular}{|c|c|c|c|c|c|}
\hline $\begin{array}{c}\text { Landform } \\
\text { Type }\end{array}$ & $\begin{array}{c}\text { Extent } \\
\text { Area } \\
\left(\mathbf{k m}^{2}\right)\end{array}$ & $\begin{array}{c}\text { Evident } \\
\text { Points }\end{array}$ & $\mathbf{w}^{+}$ & $\mathbf{w}^{-}$ & $\mathbf{C}$ \\
\hline $\begin{array}{c}\text { Swamp } \\
\text { Land }\end{array}$ & 254,8 & 158 & 0,433 & 0,00 & 0,433 \\
\hline $\begin{array}{c}\text { Low } \\
\text { Wavy Hill }\end{array}$ & 79,64 & 32 & $-0,433$ & 0,00 & $-0,433$ \\
\hline
\end{tabular}




\section{Conclusion}

The presence of HC microseepage in Jambi Merang area detected by Sentinel 2 image is closely related to the presence of anomalous expression of clay-carbonate, ferric iron, ferrous iron, and geobotanic anomalies such as low vegetation density, low vegetation pigment content, and presence senescence phenomenon. The distribution of HC microseepage in this area is generally agglomerated in the northeast region with a linear pattern to the Merang River flow and to the south around the oil and gas field with a tendency of autocorrelation patterns to spread throughout the study area. The potential high seepage area of micro hydrocarbon identified $488.3 \mathrm{Ha}$ or $1.46 \%$ of the total area of research.

In addition, the occurrence of micro-hydrocarbon seepage in Jambi Merang area is commonly located in Kasai Formation dominated by tuffan lithology, in areas close to the presence of fault, as well as on the swampland landform. The occurrence of hydrocarbon seepage on the characteristics of the area is closely related to geological and geomorphological conditions, ie tuffan stratigraphic characteristics with porosity for both hydrocarbon migration, swamp precipitation area conditions as hydrocarbon resources, as well as a fault which is the opening structure for hydrocarbon migration.

\section{Acknowledments}

This research is financially supported by PITTA grant from Directorate of Research and Community Service Universitas Indonesia with contract number 2313/UN2.R3.1/HKP.05.00/2018.

\section{References}

[1] Jamaludin, Ikhwan Muhammad., Abd Nasir Matori., Khin Cho Myint. (2015). Application of NIR to Determine Effects of Hydrocarbon Microseepage in Oil Palm Vegetation Stress. Space Science and Communication: 215-220

[2] Lammoglia, Talita., \& Carlos Roberto de Souza Filho. (2013). Unraveling Hydrocarbon Microseepages in Onshore Basins Using SpectralSpatial Processing of Advanced Spaceborn Thermal Emission and Reflection Radiometer (ASTER) Data. Survei Geophysic Journal No. 34:349-373

[3] Tian, Qingjiu. (2012). Study on Oil-Gas Reservoir Detecting Methods Using Hyperspectral Remote Sensing. Remote Sensing and Spatial Information Science Vol, XXXIX-B7:157-162

[4] Clark, R, H., Cleverly, R, W. (1991). Petroleum Seepage and Post Accumulation Migration, Spec, Publication, 59 (1): 265-271

[5] Salati, Sanaz., Frank van Ruitenbeek., Freek van der Meer., Babak Naimi. (2014). Detection of Alteration Induced by Onshore Gas Seeps from
ASTER and WorldView-2 Data. Remote Sensing, 6: 3188-3209

[6] Hong, Yang. (1999). Imaging Spectrometry for Hydrocarbon Microseepage. Delf: Thesis TU Delf University

[7] Asadzadeh, Saeid., \& Carlos Roberto de Souza Filho. (2017). Spectral Remote Sensing for Onshore Seepage Characterization: A Critical Overview. Earth Science Reviews 168:48-72

[8] Scafutto, Rebecca Del'Papa M., Carlos Roberto de Souza Filho., Wilson Jose de Oliveira. (2017). Hyperspectral Remote Sensing Detection of Petroleum Hydrocarbon in Mixture with Mineral Substrates: Implication for Onshore Exploration and Monitoring. ISPRS Journal of Photogrammetry and Remote Sensing 128:146157

[9] Avcioglu, Emme. (2010). Hydrocarbon Microseepage Mapping Via Remote Sensing for Gemrik Anticline, Bozova Oil Field, Adiyaman, Turkey. Ankara: Thesis Geodetic and Geographic Information Technologies Department, Middle East Technical University

[10] Shahi, H. Kamkar Rouhani. (2014). A GIS-based weights-of-evidence model for mineral potential mapping of hydrothermal gold deposits in Torbate-Heydarieh Area. Journal of Mining \& Environment, Vol.5, No.2: 79-89

[11] Pour, Amin Beiranvand, Mazlam Hashim, John van Genderen, (2013), Detection of Hydrothermal Alteration Zones in a Tropical Region Using Satellite Remote Sensing Data: Bau Goldfield, Sarawak, Malaysia, Ore Geology Reviews No, 54: 181-196

[12] Arellano, Paul, Kevin Tansey, Heiko Balzer, Doreen S Boyd, (2015), Detecting the Effect of Hydrocarbon Pollution in the Amazon Forest Using Hyperspectral Satellite Images, Environmental Pollution Vol, 205: 225-239

[13] Renier, Cecile., Francois Waldner., Damien Christophe Jacques., Mohamed Abdallahi Babah Ebbe., Keith Cressman., Pierre Defourny. (2015). A Dynamic Vegetation Senescence Indicator for Near-Real-Time Desert Locust Habitat Monitoring with MODIS. Remote Sensing (7): 7545-7570

[14] Wibowo, Susanto Sigit., Eddy A, Subroto. (2017). Studi Geokimia Dan Pemodelan Kematangan Batuan Induk Formasi Talangakar Pada Blok Tungkal, Cekungan Sumatera Selatan. Bulletin of Geology, Vol. 1, No. 1: 54-64

[15] Kartz, Barry. (2001). Controlling Factors on Source Rock Development- A Review of Productivity, Preservation, And Sedimentation Rate. Journal of Paleolimnology 26(2):161-179 